\title{
Same same, but different: capital structures in single family offices compared with private equity firms
}

\author{
Antonia Schickinger (D) - Alexandra Bertschi-Michel • \\ Max P. Leitterstorf • Nadine Kammerlander
}

Accepted: 3 January 2021 / Published online: 29 January 2021

(C) The Author(s) 2021

\begin{abstract}
Despite the increasing interest in single family offices (SFOs) as an investment owned by an entrepreneurial family, research on SFOs is still in its infancy. In particular, little is known about the capital structures of SFOs or the roots of SFO heterogeneity regarding financial decisions. By drawing on a hand-collected sample of 104 SFOs and private equity (PE) firms, we compare the financing choices of these two investor types in the context of direct entrepreneurial investments (DEIs). Our data thereby provide empirical evidence that SFOs are less likely to raise debt than PE firms, suggesting that SFOs follow pecking-order theory. Regarding the heterogeneity of the financial decisions of SFOs, our data indicate that the relationship between SFOs and debt financing is reinforced by the idiosyncrasies of entrepreneurial families, such as higher levels of owner management and a higher firm age. Surprisingly, our data do not support a
\end{abstract}

\footnotetext{
A. Schickinger $(\bowtie) \cdot$ N. Kammerlander

WHU-Otto Beisheim School of Management, Burgplatz 2,

56179 Vallendar, Germany

e-mail: antonia.schickinger@whu.edu

N. Kammerlander

e-mail: nadine.kammerlander@whu.edu

A. Bertschi-Michel

University of Bern, Engehaldenstrasse 4, 3012 Bern, Switzerland e-mail: alexandra.bertschi@iop.unibe.ch

M. P. Leitterstorf

Hochschule Bonn-Rhein-Sieg, Grantham-Allee 20, 53757 Sankt

Augustin, Germany

e-mail: max.leitterstorf@h-brs.de
}

moderating effect for the emphasis placed on socioemotional wealth (SEW).

Keywords Entrepreneurial family · Single family office $\cdot$ Private equity $\cdot$ Capital structure

JEL classifications $\mathrm{C} 12 \cdot \mathrm{C} 83 \cdot \mathrm{G} 11 \cdot \mathrm{G} 23 \cdot \mathrm{G} 32 \cdot \mathrm{L} 26$

\section{Introduction}

A single family office (SFO) is an organizational entity owned by a single entrepreneurial family that manages, among other things, the assets of the respective family while pursuing a long-term orientation (Zellweger and Kammerlander 2015). Although SFO research is still in its infancy (Welsh et al. 2013), SFOs have increasingly become an important investment vehicle (e.g., Welsh et al. 2013; Wessel et al. 2014; Zellweger and Kammerlander 2015). Therefore, specifically, after the sale of the original family firm, the SFO may become the new entrepreneurial (Zellweger et al. 2010) and financial (Bierl and Kammerlander 2019) focus of the respective family. Consequently, decisions regarding the capital structure of SFOs are key, especially when SFOs make external direct entrepreneurial investments ${ }^{1}$

\footnotetext{
${ }^{1}$ DEI are (partial) acquisitions of established/mature firms with a proven business model (Bierl and Kammerlander 2019); these acquisitions are carried out in a "direct" manner (i.e., not via funds).

${ }^{2} \mathrm{PE}$ firms specialize in equity investments in mature firms and raise funds from third-party investors; they establish fund structures with a predefined lifetime and generally use debt to increase return on equity (e.g., Dawson 2011).
} 
(DEIs) and thus compete with private equity (PE) firms ${ }^{2}$ (Block et al. 2019; Rottke and Thiele 2018) that have no family background and multiple professional investors.

Previous studies on capital structures highlight the impact of ownership on financial decisions (Bopaiah 1998). PE firms, for example, were found to predominantly follow the trade-off theory (Gompers et al. 2016), which recognizes that debt is usually cheaper than equity but, at the same time, increases financial distress and bankruptcy risk (Harris and Raviv 1991; Stulz 1990), which leads PE firms to strive to have an optimal mix of equity and debt (Axelson et al. 2013; Gompers et al. 2016). Business-owning families, in contrast, generally prefer internal over external financing sources, which is in line with pecking-order theory (e.g., Gallo and Vilaseca 1996; Reid et al. 1999) and predicts that differences in agency costs influence financial decisions and result in hierarchical preferences for internal financing options. This preference for internal financing is followed by a preference for external debt and, lastly, equity (Myers 1984; Myers and Majluf 1984).

However, extant academic research analyzing (debt) financing in family vs. nonfamily structures has found ambiguous empirical evidence (e.g., Anderson and Reeb 2003; González et al. 2013) about whether entrepreneurial families raise more debt (e.g., Gottardo and Moisello 2014) or less (e.g., Ampenberger et al. 2013; Mishra and McConaughy 1999). Hence, particularly in family-owned entities, traditional capital structure theories alone might not sufficiently explain debt preferences. Building on this, the behavioral agency model (BAM) suggests that debt financing decisions are not static but are largely driven by loss aversion (Wiseman and Gómez-Mejía 1998), which is higher when an owning family is involved (Gómez-Mejía et al. 2007). This finding is particularly salient in the context of the capital structure decisions of entrepreneurial families outside the family firm (i.e., in an SFO), as SFOs are at the intersection between financial decision-making and family cohesion and thus constitute a fruitful context for debt discussions (Rivo-López et al. 2017; Wessel et al. 2014). Furthermore, SFO decision-making is affected by the unique aspects of family involvement, such as combined ownership management (e.g., Hutchinson 1995; Pierce et al. 2001), transgenerational intentions (e.g., González et al. 2013; Schulze et al. 2003), and the pursuit of noneconomic goals related to socioemotional wealth (SEW) (e.g., Gómez-Mejía et al. 2007; Molly et al. 2019).
Surprisingly, academic knowledge on the influence of SFO-owning families on capital structure decisions as well as how entrepreneurial families' unique idiosyncrasies (e.g., owner-management, transgenerational intentions, SEW) affect such decisions is still limited. Thus, we pose the following research questions: How do SFOs and PE firms differ in terms of debt financing in the context of DEI? How do factors such as owner management, firm age, or the importance of SEW influence the use of debt for SFOs? To answer these research questions, we draw on capital structure theories (tradeoff and pecking-order; Myers 1977, 1984) and the BAM (Wiseman and Gómez-Mejía 1998) to derive hypotheses for the debt financing preferences of SFOs (compared with PE firms) as well as on the influence of entrepreneurial families' idiosyncrasies on the relationship between SFOs and capital structure. We empirically test our hypotheses on a hand-collected sample of 104 SFOs and PE firms. Overall, we reveal a significant, negative relationship between SFOs (compared to PE firms) and debt financing. Moreover, we find that the degree of owner management and firm age negatively impact the direct effect. Counterintuitively, we do not find empirical evidence for an interaction with SEW.

Our study contributes to the academic literature in at least two important ways. First, our empirical findings add to the literature on SFOs and their capital structure decisions (e.g., Bacci et al. 2018; Gottardo and Moisello 2014; Koropp et al. 2013) by comparing SFOs (with a family background) with PE firms (without any family influence). Our data provide empirical evidence that familyowned SFOs favor relying solely on internal financing and only raising debt when no internal financing is available. This finding expands extant knowledge on SFOs' debt financing decisions (i.e., Molly et al. 2019) by showing that due to their unique structures, SFOs follow pecking-order theory and thereby strongly differ from PE firms (Gallo and Vilaseca 1996; Gompers et al. 2016).

Second, we contribute to the literature on the heterogeneity among SFO capital structures stemming from the unique idiosyncrasies of the involvement of an entrepreneurial family (Block et al. 2018; Welsh et al. 2013; Zellweger et al. 2012b). In particular, we analyze the moderating effects of owner management, firm age, and the importance of SEW on debt financing decisions of SFOs. We provide empirical evidence that increased levels of owner management and firm age, along with loss aversion (Chrisman and Patel 2012), further decrease the propensity of SFOs to seek debt financing. 
Counterintuitively, and in contrast with extant research (Gómez-Mejía et al. 2007), our data do not provide evidence for SEW being a relevant contingency. We might speculate that either SEW is also important to nonfamily structures (i.e., PE firms) or that the importance of SEW generally does not affect financial decisions (Molly et al. 2019).

\section{Theoretical background}

\subsection{Capital structure theories in family firms}

Researchers have long studied capital structures of different firm types and have sought to explain - among other things - the mix of equity and debt for a firm and what factors influence the underlying decision-making process (Gompers et al. 2016). However, given the multitude of factors influencing financial decisions (Myers 2001), our understanding of capital structure decisions in family entities remains incomplete.

The trade-off theory predicts an optimal capital structure (i.e., a target debt to equity ratio) based on the balance between the costs and benefits of using debt (Harris and Raviv 1991; Myers 1977; Stulz 1990). The foremost advantages of debt financing are the tax-deductibility of interest payments (called "tax shield") and the potential avoidance of liquidity issues. However, a high level of debt also involves the costs of financial distress, a higher bankruptcy risk (Kraus and Litzenberger 1973), and the costs of the information asymmetries between shareholders and creditors (Jensen and Meckling 1976). Hence, the resulting optimal capital structure differs among firms, depending on the firm's characteristics, available assets, and business models (Myers 1984).

In contrast with trade-off theory (which solely distinguishes between equity and debt), pecking-order theory (Myers 1984; Myers and Majluf 1984) assumes that there is no optimal capital structure. Specifically, decision-makers have the objective of minimizing the costs of the information asymmetries between internal and external agents because such costs (e.g., monitoring and transparency requirements) might result in less favorable debt conditions. Pecking-order theory thus postulates that in cases of information asymmetries, financing decisions are based on hierarchical preferences. Specifically, decision-makers will opt for internal financing and will only opt for the capital market if internal financing options are insufficient (Myers 1984).
While originally developed for publicly traded firms, an increasing number of scholars also apply the two theories in the context of private structures (Michaelas et al. 1999), for which the outcomes, however, seem to be more nuanced than for other types of firms. For example, scholars widely agree that PE firms primarily follow the trade-off theory (Gompers et al. 2016) and raise as much debt as they can (Axelson et al. 2013, Gompers et al. 2016). In contrast, some family firm financing researchers find that families follow a pecking-order hierarchy and prefer external debt over external equity when additional financing is sought (Blanco-Mazagatos et al. 2007; Poutziouris 2001), whereas other studies indicate a negative relation between family ownership and debt financing in both public and private family firms (Gallo and Vilaseca 1996; Mishra and McConaughy 1999). The latter is explained by the fear of bankruptcy and the aim to maintain control (Gallo and Vilaseca 1996; Mishra and McConaughy 1999). Although these studies highlight differences among business families regarding the willingness to use debt, they indicate a general preference for internal over external financing options and thus follow a hierarchical approach in line with peckingorder theory.

To explain the observed heterogeneity in family firm capital structures, several scholars emphasize the need for the integration of nontraditional theoretical approaches, such as incorporating behavioral aspects. For example, Hutchinson (1995) stresses that behavioral aspects mitigate the demand for financing in small owner-managed firms. Other scholars emphasize that risk aversion and owners'/managers' individual goals affect debt financing (Barton and Matthews 1989; Romano et al. 2001). Given that behavior might serve as an explanation for why entrepreneurial families prefer certain capital structures, in the following, we analyze the interaction of the BAM and traditional capital structure theories to increase our understanding of financing decisions.

2.2 The role of the behavioral agency model and loss aversion in capital structures

Financial decisions and risky decision-making can often be explained by the BAM (Wiseman and Gómez-Mejía 1998), which challenges the general assumption of static risk-taking preferences but suggests that decisions are based on problem framing and loss aversion (Cyert and 
March 1963; Wiseman and Gómez-Mejía 1998), which means that decisions are evaluated against potential gains and losses (Gómez-Mejía et al. 2010; Kahneman and Tversky 1979) and that the prevention of losses is considered more important than obtaining gains (Chrisman and Patel 2012). However, to date, findings on family firm decision-making processes with respect to their capital structure are mixed.

Concerning the level of debt, González et al. (2013), for instance, find that the need for financial growth without the loss of control leads to higher debt levels. Additionally, they find that older firms tend to raise more debt than younger firms, which they relate to the founders' assumed high levels of risk aversion compared with that of their heirs (e.g., González et al. 2013; King and Santor 2008). Studies showing that family firms raise similar debt levels as nonfamily firms (e.g., Anderson and Reeb 2003) indicate that businessowning families do not adjust their capital structure decisions to reduce risk (Amore et al. 2011; Anderson and Reeb 2003). In contrast, studies finding a negative effect of family ownership on debt financing (e.g., Ampenberger et al. 2013; Mishra and McConaughy 1999), especially for family firms with a high market share within the respective industry (Gallo and Vilaseca, 1996), indicate a higher fear of bankruptcy (often associated with personal bankruptcy) and a stronger identification of the family with the firm.

Although the academic literature has, to date, yielded inconsistent findings with respect to the debt levels of family vs. nonfamily firms, most studies stress that business-owning families prefer internal over external financing options (e.g., Gallo and Vilaseca 1996; Reid et al. 1999) due to owners'/manager's pursuit of noneconomic values and the fear of loss of control, thus producing their risk aversion (e.g., Barton and Matthews 1989; Romano et al. 2001). However, if internal financing options are insufficient, then business-owning families might first turn to debt before considering equity (e.g., Anderson and Reeb 2003; González et al. 2013), in line with pecking-order theory.

While extant research has primarily focused on the drivers of capital structure decisions within the family firm, the influence of entrepreneurial families on debt financing may be even more salient in financing decisions outside the family firm, such as in an SFO. SFOowning families likely differ from business-owning families in their preferences for raising debt, although both types basically rely on an entrepreneurial family
(Schickinger et al. 2020). In particular, these types of entities differ to a certain extent in terms of their governance structures (a united group of family owners vs. the SFO as an intermediary structure; Zellweger and Kammerlander 2015), portfolio of investments (original family firm vs. outside entrepreneurial investments; Bierl and Kammerlander 2019), entrepreneurial behavior across generations (the intention to pass on entrepreneurial investments to the next generation or not; Schickinger et al. 2020), or preferences regarding financial resources (debt vs. equity). With respect to the latter, SFOs are more likely to focus on internal financial resources to avoid external pressure, whereas family firms often require funding for technological enhancements or market extensions to remain competitive (e.g., Sirmon and Hitt 2003). Increasing our academic understanding of the debt preferences of SFOs seems crucial to gain a more holistic picture of entrepreneurial families' external debt financing choices.

\section{Hypotheses development}

\subsection{The impact of SFOs versus PE firms on capital} structure

To further investigate families' capital structure decisions outside the family firm, we follow recent calls of SFO scholars that stress the importance of comparing SFOs with other types of investors without a family background, such as PE firms (Block et al. 2019; Rottke and Thiele 2018). To do so, we shed light on the key benefits and costs that, according to capital structure theories (trade-off and pecking-order) (Myers 1977, 1984) as well as the BAM (Wiseman and GómezMejía 1998), come with debt financing in the context of DEI investments: the benefit of deductible interest payments and the cost of financial distress (Kraus and Litzenberger 1973). With regard to the benefits of deductible interest payments, we assume that the interest tax shield is identical for both SFOs and PE firms, whereas regarding the costs of financial distress, the line of argument is linked first to diversification and, second, to bankruptcy consequences.

First, although SFOs are generally well diversified in terms of their overall portfolio (Rivo-López et al. 2017), they often suffer from an inadequately diversified allocation of DEI due to their large investments in single portfolio firms and their frequent aversion to external 
financing, corresponding with pecking-order theory. In contrast, as PE firms, which frequently following the trade-off theory, draw capital from multiple external investors, their assets under management in DEI are generally higher than those of an SFO (Block et al. 2019), which enables PE firms to better diversify regarding firm size or firm life cycle (Rottke and Thiele 2018). Second, bankruptcy consequences are more severe for SFO-owning families because of the family's wealth concentration and their private benefits as prescribed by the BAM (Cyert and March 1963; Wiseman and Gómez-Mejía 1998). Thus, the BAM predicts that the cost of financial distress is higher for SFOs (similar to family firms) than for PE firms (similar to nonfamily firms) (c.f. López-Gracia and Sánchez-Andújar 2007). In sum, the risk associated with debt increases in lessdiversified portfolios (such as for SFOs), and financial hardship is higher for loss-averse SFO-owning families. Hence, according to the BAM, we propose that SFOs are less likely to use higher debt levels than PE firms.

Moreover, since SFOs are entities that are funded with family equity, their investment decisions depend on the respective family but are typically independent of predefined targets (Bierl and Kammerlander 2019; Rottke and Thiele 2018). Therefore, SFOs benefit from the option of solely relying on internal financing (their first hierarchical preference with zero leverage; Myers 1984) when making DEIs. In contrast, PE firms generally require debt to meet predefined, often ambitious returns for investors (Dawson 2011). Thus, based on pecking-order theory and the BAM, we expect SFOs to be less likely to use the same or higher debt levels than PE firms because SFOs have the option of relying on internal financing (and thereby avoiding bankruptcy risk) instead of raising debt, whereas PE firms need to use debt to achieve predefined returns. In sum, we hypothesize the following:

Hypothesis 1 (H1): Single family offices raise less debt when financing direct entrepreneurial investments than PE firms.

\subsection{The moderating effect of entrepreneurial family idiosyncrasies on investment decisions}

While ownership structure may impact debt financing decisions, as just hypothesized, this relationship is likely further affected by three characteristics that are idiosyncratic to family investors (Gómez-Mejía et al. 2018). First, the overlap of ownership and management structures typically results in a sense of high psychological ownership towards the firm and a correspondingly increased need for control (e.g., Bacci et al. 2018; Pierce et al. 2001; Romano et al. 2001). Second, firms with a family background often span generations and are thus old and well established in their environment, which increases the intention to establish transgenerational control (e.g., González et al. 2013; Schulze et al. 2003; Zellweger et al. 2012a). Third, business families pursue noneconomic goals (e.g., Molly et al. 2019) related to SEW and thus seek to protect their SEW endowment (Gomez-Mejia et al. 2007). In the following, we analyze how these typical idiosyncrasies moderate the relationship between ownership structure and debt financing.

\subsubsection{The moderating effect of owner management}

In SFOs, financial decisions are frequently made by the owning families (shareholders) who are the sole investor in the financial structure (Rottke and Thiele 2018). The extant literature has revealed that such family owner managers may have a sense of greater psychological ownership towards the firm due to their autonomy and independent decision-making (Douglas and Shepherd 2000; Pierce et al. 2001), family tradition, close bonds between members, or nostalgia about the past (Sharma and Manikutty 2005). Therefore, psychological ownership has been found to be a key driver of loss aversion (Ariely et al. 2005; Chrisman and Patel 2012; Townsend et al. 2009) — which might further strengthen the financing preferences noted before. Thus, in line with peckingorder theory, we assume that psychological ownership may encourage owner managers of SFOs to avoid debt financing because of the fear of a loss of control.

Similarly, previous literature found that owner managers of family structures (i.e., SFOs) are generally more risk- and loss-averse than nonowner managers or owner managers of nonfamily structures (i.e., PE firms) (Gallo et al. 2004; McConaughy et al. 2001). Hence, although pecking-order theory emphasizes that debt is preferred as an external financing option, family owner managers often associate additional costs (i.e., monitoring, controlling) and fears (loss of control) with the use of external financing (McConaughy et al. 2001). In contrast, PE owner managers are less likely to face such aversion towards external financing because PE funds already generate highly regulated and formal reports for 
auditors and investors (Rottke and Thiele 2018). In sum, we argue that the more profound psychological ownership (Ariely et al. 2005) and the general loss aversion of SFO-owning families are (Gallo et al. 2004; McConaughy et al. 2001), the more negative the attitude of the SFO towards debt financing for DEI will be. Hence, we argue the following:

Hypothesis $2(\mathrm{H} 2)$ : The relationship between the type of investor and the likelihood of debt financing for direct entrepreneurial investments is moderated by owner management. Specifically, single family offices, in contrast with PE firms, have even less debt when the percentage of shareholders on the management board increases.

\subsubsection{The moderating effect of firm age}

Moreover, the structures of SFOs are frequently characterized by a long period of family ownership often approximated with firm age (Zellweger et al. 2012a). Such extended ownership periods might positively influence access to debt financing because of longer track records and banking relationships (Michiels and Molly 2017). However, over a longer period of ownership, the identity of the respective owner is often inextricably linked with the identity of the firm (Berrone et al. 2010; Cruz et al. 2010), and family owners seek transgenerational control (Zellweger et al. 2012a). While some scholars argue that founders are more risk-averse than their descendants (Gómez-Mejía et al. 2007; González et al. 2013), the majority of studies highlight that descendants are generally more risk- and loss-averse (Molly et al. 2012; Schulze et al. 2003). Accordingly, Reid et al. (1999) find that firm age negatively affects the use of debt because older family firms led by descendants show increased levels of fear of losing control and/or wealth.

In the context of SFOs, we expect a similar relationship because the SFO might become the new emotional anchor of the family, especially after the sale of the original family firm (Bierl and Kammerlander 2019). Thus, firm age may strengthen the negative relationship between SFOs and debt financing because changes in reference points over time (e.g., through succession) may foster loss aversion (Kahneman and Tversky 1979) and mitigate risk-taking behavior (Kempers et al. 2017). In line with the literature, we argue that the new reference point of SFO-owning families is inherited wealth and the inextricable link of family identity to the SFO (c.f., Berrone et al. 2010; Cruz et al. 2010). In contrast, PE firms may be less likely to become risk- and loss-averse over time becausebuilding on trade-off theory - their predefined targets (Dawson 2011) encourage PE firms (independent of age) to raise as much debt as they can. The higher the return on equity is, the higher the compensation for $\mathrm{PE}$ managers and the higher the satisfaction of investors will be (Chung et al. 2012).

In sum, we argue that SFOs have even less debt when firm age increases as changes in reference points of SFO-owning families foster the pecking-order approach and loss aversion. Thus, SFOs may define less ambitious performance targets than PE firms and consequently raise even lower debt levels to meet these demands. Hence, we argue the following:

Hypothesis 3 (H3): The relationship between the type of investor and the likelihood of debt financing for direct entrepreneurial investments is moderated by firm age. Specifically, single family offices, in contrast with PE firms, have even less debt when firm age increases.

\subsubsection{The moderating effect of the importance of SEW}

Finally, while family firm research generally links the importance of SEW to the family firm itself (Chirico et al. 2019), recent findings also acknowledge its importance for SFOs, which may even persist after the sale of the family firm (Schickinger et al. 2020). First, the desire to perpetuate family control, an important SEW dimension, may decrease the debt financing of SFOs because families aim to maintain transgenerational control and influence in the long term (Block et al. 2018; Lumpkin and Brigham 2011). Specifically, raising debt from external creditors is, according to pecking-order theory, typically accompanied by increasing information asymmetries (Myers 1984) and monitoring requirements (Barry and Mihov 2015), which might diminish family control and influence within the SFO. In contrast, maintaining control and avoiding transparency towards creditors may be less pressing for PE firms because of their nonfamily structure and regulated nature, causing them to file reports for auditors and investors independent of creditor requirements (Rottke and Thiele 2018). 
Second, the pursuit of SEW-related goals may further decrease debt financing of SFOs due to the higher costs of financial distress (Gallo and Vilaseca 1996; Mishra and McConaughy 1999; Strebulaev and Yang 2013), as raising debt increases the risk of bankruptcy and a corresponding loss of SEW. Given that entrepreneurial families are loss averse (Cyert and March 1963; Wiseman and Gómez-Mejía 1998), the increasing economic utility from financing (large-scale) projects with debt may not outweigh the additional risk of losing SEW. In contrast, such SEW-related reasons may affect PE firms less than SFOs because of their nonfamily structure and their ambitious performance targets (Mietzner and Schweizer 2014), which limit them from considering noneconomic goals at the expense of profits.

In sum, we argue that entrepreneurial families also consider noneconomic aspects that meet affective needs (Gómez-Mejía et al. 2007) and are loss-averse when SEW is threatened. In line with pecking-order theory, these families aim to rely on as much internal financing as possible to maintain family control within the SFO (Block et al. 2018). Moreover, raising debt would increase bankruptcy risk and consequently the risk of losing SEW (Mishra and McConaughy 1999; Strebulaev and Yang 2013), whereas internal financing options would preserve SEW. Thus, we argue the following:

Hypothesis 4 (H4): The relationship between the type of investor and the likelihood of debt financing for direct entrepreneurial investments is moderated by the importance of SEW. Specifically, single family offices, in contrast with PE firms, have even less debt when the importance of SEW increases.

\section{Methodology}

\subsection{Sample and data collection}

We test our hypotheses using a sample of Germanspeaking SFOs and PE firms because entrepreneurial families represent the backbone of the German, Austrian, and Swiss economies and have a long-standing tradition (De Massis et al. 2018). We performed multiple steps to identify study participants given the immense lack of transparency and the difficulty in obtaining reliable information on SFOs and PE firms (Amit et al. 2008; Cumming and Groh 2018). Specifically, in the context of SFOs, it is challenging to obtain access to study participants because SFOs are privately held, generally have no legal obligation to disclose information, and often minimize public appearances to maintain their confidential nature (Decker and Lange 2013). As such, previous SFO and PE studies generally rely on small sample sizes (Welsh et al. 2013, Michels et al. 2020). Moreover, we further constrained our study because we only included SFOs with a focus on DEI. Given that only a limited portion of all SFOs conduct DEI, we could only determine whether an SFO had experience with DEI during private discussions with representatives of SFOs.

The study included three phases of data collection. First, we identified possible SFO study participants and conducted semistructured interviews with family members or senior managers of SFOs. Second, we identified possible PE study participants and conducted interviews with PE managers. Third, we collected data from the Amadeus database, which includes ownership information for firms based in Europe.

\subsubsection{Phase 1: Search process and semistructured interviews with SFOs}

Given that there is no complete database on Germanspeaking SFOs, we identified potential study participants in multiple steps. First, we based our search process on the Listenchampion database (Listenchampion 2017) (86 SFOs) and the (partial) member list of $\mathrm{VuFO}^{3}$ (13 SFOs). Next, we included 146 SFOs via manual and extensive internet research and 105 SFOs via individual contacts, resulting in a database of 350 Germanspeaking SFOs. In the last step, we eliminated 54 SFOs because of their real estate focus and 25 SFOs because of their liquidated or pure offshore structures, obsolete postal addresses, or inapplicable SFO types (i.e., multifamily offices). The final list included 271 Germanspeaking SFOs.

In August 2017, we physically mailed a short research introduction and followed up by phone and email. Ultimately, 109 SFOs agreed to participate in our study. However, we focused on only 53 SFOs because they actively engaged in DEIs. Out of these 53 SFOs, we had to exclude three SFOs because they sent their questionnaire responses by email with 
questionable data quality (two SFOs) or were in the process of planning a DEI (one SFO), resulting in a final list of $50 \mathrm{SFOs}$ and a response rate of $18 \%$ (based on the 271 identified SFOs). Between September 2017 and June 2018, we conducted interviews with a family member ( $56 \%$ of the SFOs) or a senior manager (44\% of the SFOs) of the SFOs. Seventy percent of all interviews were conducted in personal meetings and $30 \%$ were conducted by phone. In terms of regional allocation, $92 \%$ of all SFO interviewees were based in Germany and 4\% were in Switzerland and Austria each.

\subsubsection{Phase 2: Search process and semistructured interviews with PE firms}

Similar to the search process for SFOs, we identified PE study participants in several steps and focused on smallto mid-cap PE firms. First, we based our sample on the Listenchampion database (Listenchampion 2018) (74 PE firms). Next, we included 26 PE firms via extensive and manual research and personal contacts, resulting in 100 German-speaking small- to mid-cap PE firms.

In March 2018, we sent a short research introduction by email and followed up by phone and email. Ultimately, 55 PE firms agreed to participate. In line with the SFO procedure, we excluded one PE firm because it sent its questionnaire responses by email, resulting in 54 PE firms (and a response rate of 54\%). We interviewed CEOs (44\%) and senior managers (56\%) until June 2018. The interviews were conducted by phone $(82 \%)$ or in personal meetings (18\%). A total of $98 \%$ of all interviewees were based in Germany and $2 \%$ were based in Switzerland.

\subsubsection{Phase 3: Quantitative database research}

In addition to the interviews, we supplemented our dataset with public information on ownership and management structures from the Amadeus database in January 2018 and obtained information on all 104 participating firms. We regarded Amadeus (Bureau van Dijk) as an adequate source because it contains detailed ownership information, data on board members and the number of shares held and ensures that its records are updated through regulatory filings and its own proprietary sources.

\subsection{Common method bias}

We took several steps before and during the data collection process to minimize the risk of common method bias. First, given that our questionnaire items were primarily fact-based (Tourangeau et al. 2000), our variables are unlikely to be affected by such issues (Chang et al. 2010; Crampton and Wagner 1994). Second, our study variables were embedded in a comprehensive questionnaire on entrepreneurial behavior, activities, and organizational structures and did not reveal any potential, assumed relationships among constructs. It is thus unlikely that the interviewees adjusted their answers in line with expectations. Third, we assured strict confidentiality and thereby minimized the probability of socially desirable answers (Podsakoff et al. 2003).

Additionally, we conducted the Harman single factor test (Podsakoff and Organ 1986), a principal component factor analysis of all the study variables. The analysis revealed three factors with eigenvalues greater than one, with no single factor explaining the majority of variance. Moreover, we conducted a marker variable test to investigate correlations between the dependent variable (i.e., debt financing) and the marker variable (i.e., the importance of human capital in the target portfolio firm $^{4}$ ), which are theoretically unrelated to and uncorrelated with the focal variables (Lindell and Whitney 2001). The significances of the correlations between the main and revised models were not substantially different (Van Doorn and Verhoef 2008). In sum, common method bias will unlikely distort the findings of our study (Podsakoff et al. 2003).

\subsection{Measures}

The survey was conducted in German. To ensure accuracy and maximum comprehensibility, we applied an iterative, two-way translation (Dickson et al. 2006) from English to German for established scales. Given that objective and public data on SFOs and PE firms are scarce (Amit et al. 2008; Cumming and Groh 2018), most measures (except for owner management) were self-reported. However, previous studies have shown that financial data, such as debt levels reported by

\footnotetext{
${ }^{4}$ Study participants were asked to indicate the importance of human capital in the decision-making process when (partially) acquiring established firms. The question was assessed on a five-point Likert scale.
} 
executives, are typically reliable (Tan and Litschert 1994), especially when reported anonymously (Dillman 1978).

\subsubsection{Dependent variable: Debt financing}

In line with Schulze et al. (2003), we measured debt financing as an ordinal-dependent variable ${ }^{5}$ of a firm's debt-to-equity ratio when financing DEI. The debt levels range from one to four, coded as " 1 " if no debt was raised, "2" for debt levels of 1-25\%, "3" for debt levels of 26-50\%, and "4" for debt levels of 51-100\%. Unlike Schulze et al. (2003), our data sample does not include debt levels over $100 \%$. We thus excluded the suggested categories " 5 " for debt levels of 101-200\% and "6" for debt levels over $200 \%$.

\subsubsection{Independent variable: Type of investor}

We measured the independent binary variable, type of investor, by assessing whether the study participant represents an SFO (coded as "1") or a PE firm (coded as " 0 ").

\subsubsection{Moderating variables}

Owner management To identify the degree of owner management, we determined the percentage of shareholders on the management board from the Amadeus database. For SFOs, we used the percentage of SFOowning family members on the management board. For PE firms, we referred to the percentage of general partners on the management board, given that general partners (in contrast with limited partners) are liable without limitation and responsible for any outstanding debt in case of bankruptcy (Veith 2008). We measured the degree of owner management as a continuous variable, ranging from 0 to 100 (percent).

Firm age To identify firm age, we determined the time between 2018 and the firm founding year (Pfaffermayr

\footnotetext{
$\overline{5}$ Throughout our interviews, our SFO study participants particularly emphasized the hierarchical preference structure of pecking-order theory (Myers 1984; Myers and Majluf, 1984): The underlying concern of debt financing for SFO-owning families is not related to the degree of debt financing but rather to whether they raise debt at all to finance DEI. We therefore collected data based on a categorical range, as suggested by Schulze et al. (2003).
}

2009). We measured firm age as a continuous variable (in years).

SEWi To identify the importance of noneconomic goals, we assessed the SEWi (socioemotional wealth importance) scale, developed by Debicki et al. (2016). This scale consists of nine questions on the importance of noneconomic aspects, rated on a five-point Likert scale (from 1 "not important" to 5 "very important"). The scale was originally developed for family firms; we applied it to our sample because (1) SFOs are closely connected to family firms and are typically established by (former) business-owning families (Bierl and Kammerlander 2019; Decker and Lange 2013) and (2) although SEW is generally linked to family ownership, PE firms may also value certain SEW characteristics (e.g., importance of reputation). After a thorough assessment throughout the interview process, we eliminated two items ${ }^{6}$ that focused on the importance of obtaining appreciation from the general public and pursuing social ties. These questions do not apply to our sample because many SFOs intentionally minimize public appearances to maintain a secretive and confidential nature (Decker and Lange 2013). The Cronbach's alphas are .61 for SFOs and .57 for PE firms, which suggest adequate internal reliability (Kline 2013). To capture the importance of SEW, we calculated the average of the seven responses of each study participant.

Control variables First, we controlled for firm size because larger organizations are more likely to raise debt than smaller ones (Harris and Raviv 1991). We measured firm size as the number of employees within the SFO or PE firm (continuous variable). Next, we controlled for club deal investments because coinvestments might trigger the perceived individual risk differently (in comparison with single investments) given that potential investment gains as well as losses are shared among multiple investors. We assessed this variable as a binary variable $(1=$ primarily club deal investor; $0=$ primarily single investor). Last, we controlled for the number of current holdings because investors with a larger number

\footnotetext{
${ }^{6}$ Eliminated survey questions: (1) "If it is important that the family gains recognition and appreciation in our community, as a firm we will engage in actions that have the greatest potential to benefit the family in this regard" and (2) "How important is it that the family can benefit from the social relationships developed through our business, and vice-versa (that the business benefits from our family's relationships)?".
} 
of holdings benefit from a higher level of portfolio diversification and might therefore be more willing to take risks when raising debt. We assessed current holdings as the number of DEIs at the time of the interview (continuous variable).

\section{Empirical results}

\subsection{Descriptive statistics}

The descriptive statistics, including the means, standard deviations, correlation matrix, and variance inflation factors for all variables, are presented in Table 1. In the regression model, we used the natural logarithm of firm size to minimize skewness. For a better interpretation, we additionally included the raw values of firm size in the presented tables. Table 1 shows acceptable levels of correlation (i.e., below the threshold of .30) between independent and control variables (Hair et al. 2010). We also addressed issues of multicollinearity and examined the variance inflation factors. Specifically, with the highest variance inflation factor at 1.85 and the mean variance inflation factor at 1.28 , the values are below the generally proposed threshold of 10 (Hair et al. 2010). These results indicate that multicollinearity is not an issue in our study. Moreover, as this study compares German-speaking SFOs to PE firms, we used $t$ test analyses to compare characteristics and to gain a better understanding of the differences among the two sample groups. We found only few significant differences in debt financing, firm size, and SEWi. These findings are presented in Table 2.

In a first step, we checked whether our sample was representative of the total population of Germanspeaking SFO and PE firms. Overall, our SFO sample accounts for $30 \%$ of the entire (estimated) SFO universe in Germany (Bierl and Kammerlander 2018), our PE sample accounts for approximately $36 \%$ of all smalland midcap PE firms in Germany (Listenchampion, 2020). We thus expect that this significant proportion of the overall population provides a representative picture. Moreover, putting this situation in a broader perspective within developed countries, we assume steady descriptive results within the PE universe because the investment concepts of PE firms are very similar internationally. In the context of SFOs, the results may vary because access to debt and cultural specifications (among others) may differ.

The sample consists of 104 firms: 50 SFOs (48.10\%) and $54 \mathrm{PE}$ firms $(51.90 \%)$. The mean debt-to-equity ratio of all the study participants is 2.32 (s.d. $=1.04$ ). The means of the debt-to-equity ratios of SFOs and PE firms show statistically significant differences $(p=.000)$. Specifically, the mean debt-to-equity ratio of SFOs is 1.86 , and the mean debt-to-equity ratio of $\mathrm{PE}$ firms is 2.74. Moreover, the average percentage of owners on the management board is $64.51 \%$ (s.d. $=$ 41.23; 65.72\% in SFOs vs. $63.39 \%$ in PE firms), and the average firm age is 17.38 years (s.d. $=11.21$ years;

Table 1 Means, standard deviations, correlation matrix, and variance inflation factors

\begin{tabular}{|c|c|c|c|c|c|c|c|c|c|c|}
\hline Variables & Mean & S.D. & 1. & 2. & 3. & 4. & 5. & 6. & 7. & 8. \\
\hline 1. Debt financing & 2.317 & 1.036 & 1.000 & & & & & & & \\
\hline 2. Firm size & 20.861 & 41.880 & $.179^{\dagger}$ & 1.000 & & & & & & \\
\hline 3. Club deal investments & .433 & .498 & .127 & .107 & 1.000 & & & & & \\
\hline 4. Current holdings & 12.238 & 17.797 & -.046 & .127 & .036 & 1.000 & & & & \\
\hline 5. Owner management & 64.510 & 41.225 & $-.182^{\dagger}$ & $-.264 * *$ & -.096 & $-.227 *$ & 1.000 & & & \\
\hline 6. Firm age & 17.375 & 11.213 & $.225 *$ & $.253 * *$ & -.054 & .086 & $-.195^{*}$ & 1.000 & & \\
\hline 7. SEWi & 3.841 & .550 & .012 & -.128 & -.014 & .110 & .040 & -.033 & 1.000 & \\
\hline 8. Type of investor & .481 & .502 & $-.427 * * *$ & $-.223 *$ & .014 & .034 & .028 & -.015 & $.225^{*}$ & 1.000 \\
\hline Variance inflation factor & 1.28 & & & 1.85 & 1.03 & 1.19 & 1.23 & 1.30 & 1.11 & 1.27 \\
\hline
\end{tabular}

$N=104 ;{ }^{\dagger} p<.1 ; * p<.05 ; * * p<.01 ; * * * p<.001$

s.d., standard deviation

Ordered DV: debt financing: (1) no debt, (2) low debt levels of 1-25\%, (3) medium debt levels of 26-50\%, (4) high debt levels of 51-100\% Binary IV: type of investor $(0=$ PE firm; $1=$ SFO $)$

$S E W i$, socioemotional wealth importance 


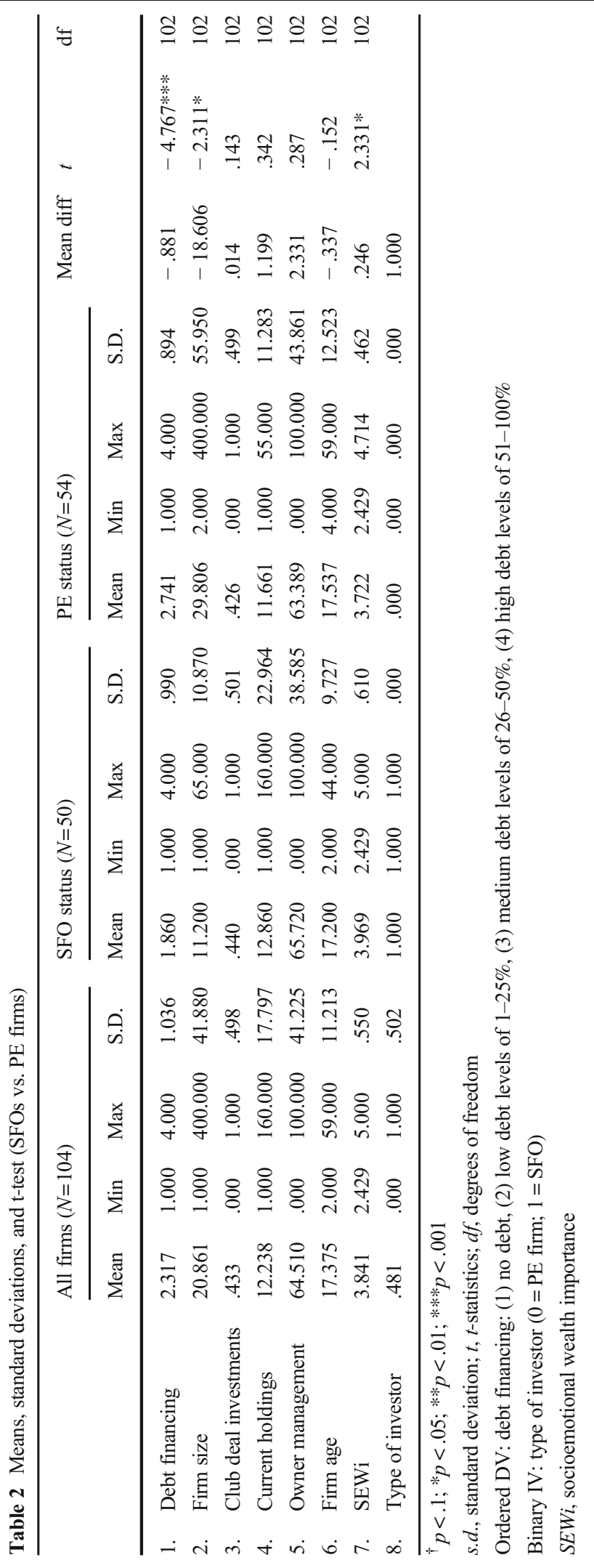


17.20 years for SFOs vs. 17.54 years for PE firms). The means of the SFOs and PE firms for these two item characteristics show no statistically significant differences. Last, the respondents rated the importance of SEW on average at 3.84 (s.d. $=.55$; based on a fivepoint Likert scale). In line with our theoretical reasoning, we find significant differences $(p=.022)$ in the mean importance of SEW between SFOs (3.97) and PE firms (3.72). Further descriptive findings are highlighted in Table 1 and Table 2.

\subsection{Regression results}

We calculated ordered logit models to test the direct and moderated effects of the binary independent variable type of investor on the ordinal dependent outcome debt financing. Table 3 presents the results of the analysis. Model 1 presents the findings of our baseline specification containing only control variables. Model 2 includes the independent variable type of investor and the moderator variables, testing for the direct effect on debt financing (H1). Model 3 adds the interaction between type of investor and owner management, firm age, and SEWi simultaneously to the former specification and allows testing for moderating effects ( $\mathrm{H} 2-4)$.

Model 1 shows that the natural logarithm of firm size is positively and significantly related to debt financing $(\beta=.626, p=.002)$. In contrast, the control variables club deal investments and current holdings are not significantly related to debt financing. Model 2 shows that the type of investor affects debt financing negatively and significantly $(\beta=-1.966, p=.000)$. This result indicates that SFOs (coded as "1") are less likely to raise high levels of debt when investing in DEI than PE firms (coded as "0"). Thus, we find empirical support for Hypothesis 1 . The pseudo- $R^{2}$ value of .138 for model 2 indicates a good model fit.

In model 3, first, the interaction between the type of investor and owner management has a negative and significant effect on debt financing $(ß=-.022$,

Table 3 Ordered logit regression of debt financing

\begin{tabular}{|c|c|c|c|c|c|c|}
\hline & \multicolumn{6}{|c|}{ Debt financing ${ }^{\mathrm{a}}$} \\
\hline & \multicolumn{2}{|l|}{ Model 1} & \multicolumn{2}{|l|}{ Model 2} & \multicolumn{2}{|l|}{ Model 3} \\
\hline \multicolumn{7}{|l|}{ Control variables } \\
\hline Firm size $(\ln )$ & $.626^{* *}$ & $(.205)$ & .070 & $(.278)$ & .099 & $(.289)$ \\
\hline Club deal investments & .497 & $(.382)$ & .566 & $(.404)$ & .629 & $(.420)$ \\
\hline Current holdings & -.018 & $(.014)$ & -.012 & $(.014)$ & -.020 & $(.014)$ \\
\hline \multicolumn{7}{|l|}{ Moderators } \\
\hline Owner management & & & -.008 & $(.005)$ & .002 & $(.007)$ \\
\hline Firm age & & & $.039^{\dagger}$ & $(.020)$ & $.072 * *$ & $(.027)$ \\
\hline SEWi & & & .652 & $(.401)$ & .101 & $(.618)$ \\
\hline \multicolumn{7}{|l|}{ Independent variable } \\
\hline Type of investor & & & $-1.966 * * *$ & $(.483)$ & -2.874 & (3.304) \\
\hline \multicolumn{7}{|l|}{ Interaction terms } \\
\hline Type of investor $\times$ owner management & & & & & $-.022 *$ & $(.010)$ \\
\hline Type of investor $\times$ firm age & & & & & $-.088^{*}$ & $(.040)$ \\
\hline Type of investor $\times$ SEWi & & & & & .982 & $(.831)$ \\
\hline Log-likelihood & \multicolumn{2}{|c|}{-114.350} & \multicolumn{2}{|c|}{-103.658} & \multicolumn{2}{|c|}{-99.130} \\
\hline Pseudo- $R^{2}$ & \multicolumn{2}{|c|}{.049} & \multicolumn{2}{|c|}{.138} & \multicolumn{2}{|c|}{.175} \\
\hline Observations & \multicolumn{2}{|c|}{104} & \multicolumn{2}{|c|}{104} & \multicolumn{2}{|c|}{104} \\
\hline
\end{tabular}

This table presents results for regressions with standard errors in parentheses

${ }^{\dagger} p<.1 ; * p<.05 ; * * p<.01 ; * * * p<.001$

${ }^{a}$ Ordered DV: debt financing: (1) no debt, (2) low debt levels of 1-25\%, (3) medium debt levels of 26-50\%, (4) high debt levels of 51-100\%

Binary IV: type of investor $(0=\mathrm{PE}$ firm; $1=\mathrm{SFO})$

SEWi, socioemotional wealth importance 
$p=.037)$. This result indicates that owner management strengthens the negative relationship between SFOs and debt financing, in line with Hypothesis 2. Second, the interaction between type of investor and firm age is negatively and significantly associated with debt financing $(\beta=-.088, p=.028)$. Thus, firm age strengthens the negative relationship between SFOs and debt financing, in line with Hypothesis 3. Last, we find that the interaction effect of the type of investor and SEWi does not significantly affect debt financing, leading us to reject Hypothesis 4 . The pseudo- $R^{2}$ value of .175 for model 3 indicates a good model fit.

\subsection{Robustness analysis}

\subsubsection{Proportional odds}

An implicit assumption of the underlying ordered logit regression is that the relationship between each outcome group is identical (parallel regression assumption). In this context, the identical relationship means that the "slope" estimates between each of the four debt levels across SFOs and PE firms are assumed to be the same. In line with best practices (Long and Freese 2014), we utilize the likelihood ratio test and the Brant test to analyze whether the parallel regression assumption has been violated. The nonsignificant statistics of the likelihood ratio test (probability $>\operatorname{chi} 2=.224$ ) and of the Brant test (probability $>$ chi $2=1.000$ ) show that our data set does not violate the parallel regression assumption. Thus, our data set is a good fit for the ordered logit model.

\subsubsection{Binary logit regression}

The results of our analysis may depend on the nature of our dependent variable, debt financing. To test their robustness, we repeat our analysis in a binary logit

Table 4 Binary logit regression of debt financing

\begin{tabular}{|c|c|c|c|c|c|c|}
\hline & \multicolumn{6}{|c|}{ Debt financing $^{\mathrm{b}}$} \\
\hline & \multicolumn{2}{|l|}{ Model 1} & \multicolumn{2}{|l|}{ Model 2} & \multicolumn{2}{|l|}{ Model 3} \\
\hline \multicolumn{7}{|l|}{ Control variables } \\
\hline Firm size $(\ln )$ & $.764 *$ & $(.271)$ & .001 & $(.366)$ & -.105 & $(.449)$ \\
\hline Club deal investments & $.877^{\dagger}$ & $(.468)$ & $1.148 *$ & $(.546)$ & $1.351^{*}$ & $(.615)$ \\
\hline Current holdings & -.033 & $(.023)$ & -.029 & $(.028)$ & -.037 & $(.031)$ \\
\hline \multicolumn{7}{|l|}{ Moderators } \\
\hline Owner management & & & $-.015^{\dagger}$ & $(.008)$ & -.004 & $(.013)$ \\
\hline Firm age & & & $.066^{*}$ & $(.033)$ & $.441 *$ & $(.172)$ \\
\hline SEWi & & & .524 & $(.485)$ & .037 & $(.902)$ \\
\hline \multicolumn{7}{|l|}{ Independent variable } \\
\hline Type of investor & & & $-2.431 * * *$ & $(.630)$ & .336 & $(4.665)$ \\
\hline \multicolumn{7}{|l|}{ Interaction terms } \\
\hline Type of investor $\times$ owner management & & & & & $-.034 *$ & $(.016)$ \\
\hline Type of investor $\times$ firm age & & & & & $-.431 *$ & $(.172)$ \\
\hline Type of investor $\times$ SEWi & & & & & 1.016 & $(1.105)$ \\
\hline Constant & $-1.067^{\dagger}$ & $(.624)$ & -.140 & $(2.270)$ & -2.900 & $(3.934)$ \\
\hline Log-likelihood & \multicolumn{2}{|c|}{-59.628} & \multicolumn{2}{|c|}{-47.890} & \multicolumn{2}{|c|}{-38.201} \\
\hline Pseudo- $R^{2}$ & \multicolumn{2}{|c|}{.102} & \multicolumn{2}{|c|}{.279} & \multicolumn{2}{|c|}{.425} \\
\hline Observations & \multicolumn{2}{|c|}{104} & \multicolumn{2}{|c|}{104} & \multicolumn{2}{|c|}{104} \\
\hline
\end{tabular}

This table presents results for regressions with standard errors in parentheses

${ }^{\dagger} p<.1 ; * p<.05 ; * * p<.01 ; * * * p<.001$

${ }^{\mathrm{b}}$ Binary DV: debt financing $(0=$ no debt to finance DEI; $1=$ debt to finance DEI $)$

Binary IV: type of investor $(0=$ PE firm; $1=$ SFO $)$

$S E W i$, socioemotional wealth importance 
regression. Thus, we analyze the direct and moderated effects on the binary dependent outcome, debt financing, coded as " 1 " if debt is raised and coded as " 0 " if no debt is raised to finance DEI. Table 4 presents the findings of the binary logit regression.

The results of the direct and moderated effects of the binary logit regression (Table 4) are similar to the results of the ordered logit regression (Table 3). First, model 2 shows that SFOs, in line with $\mathrm{H} 1$, affect debt financing negatively and significantly $(\beta=-2.431, p=.000)$, which indicates that SFOs (coded as " 1 ") are less likely than PE firms (coded as " 0 ") to use debt when investing in DEI. In model 3, in line with $\mathrm{H} 2$, the interaction between SFO and owner management has a negative and significant effect on debt financing $(\Omega=-.034$, $p=.038$ ). Moreover, the interaction between SFOs and firm age is negatively and significantly associated with debt financing $(B=-.431, p=.012)$, supporting H3. Last, in line with our previous findings, the interaction effect of the type of investor and SEWi does not significantly affect debt financing, rejecting $\mathrm{H} 4$. The pseudo$R^{2}$ value of .279 for model 2 and of .425 for model 3 indicate good model fits. In sum, these findings provide support that the results of the main model are robust to alternative model specifications.

\subsubsection{Power analysis test}

Considering the restricted sample size of 104 SFOs and PE firms, we conducted multiple power analysis tests of two independent proportions to ensure that the sample is acceptable in terms of size (Bush 2015; Cohen 1988). Pearson's chi-square test $(N=84$; $\mathrm{SFO}=40 / \mathrm{PE}$ firms $=$ $44)$, the likelihood ratio test $(N=86$; $\mathrm{SFO}=41 / \mathrm{PE}$ firms $=45)$, and Fisher's exact test $(N=104 ; \mathrm{SFO}=$ $50 / \mathrm{PE}$ firms $=54)$ provide support that our sample is acceptable, both in terms of size and independent variable distribution.

\section{Discussion}

\subsection{Implications for research and practice}

Although prior research on capital structures suggests a substantial impact of ownership on financing decisions, its empirical evidence has, to date, still been fragmented and characterized by diverging results (e.g., Mishra and McConaughy 1999), for instance, regarding the level of debt of family-owned entities compared with other types of firms (González et al. 2013; Mishra and McConaughy 1999). Extant research on capital structure decisions within the family firm has found that entrepreneurial families generally consider three types of capital in hierarchical order: internal equity, external debt, and last, external equity (Myers 1984), which follows pecking-order theory (Gottardo and Moisello 2014).

By building on these findings, in this study, we aim to go one step beyond and investigate the financial decisions and debt preferences of entrepreneurial families outside the family firm, particularly in an SFO. SFOs constitute a fruitful context for debt discussions because this type of investment vehicle allows families to distinctly and freely choose whether to raise debt (independent of market challenges). However, to date, there is a lack of research on the capital structures of SFOs, as previous studies are primarily descriptive (e.g., Decker and Lange 2013, Rivo-López et al. 2017) or qualitatively analyze (e.g., Welsh et al. 2013) the investment behavior of SFOs but fail to investigate the drivers of capital structure decisions quantitatively. This research gap is surprising given that scholars stress the need for more research on SFOs (Welsh et al. 2013) due to their unique exposition at the intersection between family financial decisions and family ownership idiosyncrasies (Rivo-López et al. 2017; Wessel et al. 2014).

To investigate SFOs' capital structure decisions, particularly their debt preferences and the influence of the unique aspects related to family ownership, we compared family-owned SFOs and PE firms. In a first step, we hypothesized and showed that SFOs follow peckingorder theory (Myers 1984; Myers and Majluf 1984) and thus raise lower levels of debt in the context of financing DEIs than PE firms, which frequently follow a trade-off approach with higher levels of debt. Moreover, in line with the BAM (Wiseman and Gómez-Mejía 1998), we argued for and empirically revealed that owner management and firm age strengthen these relationships, whereas surprisingly, the importance of SEW did not show a significant moderation effect. We propose that the significant moderation effects can be explained by increased levels of loss aversion (Ariely et al. 2005).

Our study contributes to academic research in at least the following two ways. First, we contribute to the literature on family-owned SFOs and their capital structure decisions (e.g., Bacci et al. 2018; Gottardo and Moisello, 2014; Koropp et al. 2013; Molly et al. 2019) 
by investigating debt preferences when making DEIs outside the family firm in comparison with PE firms. Our empirical findings thereby add to the literature by indicating that SFOs (compared with PE firms) are less likely to raise high levels of debt when financing DEIs than PE firms. Thus, SFOs tend to rely solely on internal financing and only raise debt when explicitly considered (independent of market challenges). The previous family firm literature has only considered family structures in which debt was potentially needed to be raised because of certain market challenges (e.g., need to grow) or in which raising external equity was the only option to remain competitive (e.g., Sirmon and Hitt 2003). Our results study a context (SFOs) in which business families can freely decide to assume debt. We show that SFOs, similar to family firms, follow pecking-order theory (Myers 1984; Myers and Majluf 1984), while PE firms follow the trade-off approach (Kraus and Litzenberger 1973). Hence, SFOs significantly differ from PE firms. SFOs as a unique unit of analysis thereby also add to the research on debt financing in general because they provide the unique opportunity to combine both perspectives of the owning family and the capital structure decisions within the investment (i.e., DEI) context.

Second, with our empirical study, we answer various calls to further investigate heterogeneity among SFO capital structures (Welsh et al. 2013) as a potential result of the idiosyncrasies stemming from the involvement of an entrepreneurial family (Block et al. 2018; Welsh et al. 2013; Zellweger et al. 2012b) by comparing them to PE firms without a family background (Rottke and Thiele 2018). Moreover, we analyze the moderating effects of owner management, firm age, and SEWi on the debt financing of SFOs. Our data support the importance of considering the moderating factors of family ownership by providing unique evidence that SFOs behave heterogeneously regarding varying degrees of owner management or firm age. In contrast, SEWi does not seem to affect the capital structure decisions of SFOs. Our descriptive results, with a mean of 3.969 for SFOs and a mean of 3.722 for PE, thereby challenge prior research stating that SEW is only linked to family structures (Gómez-Mejía, et al. 2007; Molly et al. 2019) and the existence of a family firm (Chirico et al. 2019) and indicate that nonfamily structures also regard noneconomic goals as important. A driver for the high rating of SEWi for PE firms might be the increasing importance of reputation among competitors and towards outside investors, employees, and potential sellers. Additionally, our data challenge the assumption that entrepreneurial families always consider noneconomic (GómezMejía, et al. 2007; Molly et al. 2019) goals but suggest that differences regarding financing decisions between family and nonfamily structures are based on economic considerations.

In addition to those contributions to extant research, our study also holds various practical implications. We enable SFO-owning families and managers of PE firms to benchmark themselves in terms of the debt levels and idiosyncratic effects within the same peer group as well as with their respective counterparts. Our study thereby provides transparency and a more profound understanding of competitors and investors in the SFO/PE market and might enable owners and/or managers to adapt and rethink capital structure decisions. Moreover, our findings enable external stakeholders (e.g., nonowner managers, advisors, debt suppliers, or service providers) to better understand idiosyncratic factors that impact capital structure decisions. Last, we provide sellers of established firms with more insights into a currently opaque investor market (Amit et al. 2008; Cumming and Groh 2018). Sellers of established firms may use our findings to better assess the risk-taking behavior of potential acquirers to more confidently negotiate a selling process.

\subsection{Limitations and future research}

Similar to other empirical studies, our study has some limitations, many of which provide important avenues for future research. First, although a focus on Germanspeaking SFO-owning families and PE firms is reasonable due to the economic salience in this country and the comparison of entities with a similar legal and cultural background, our results may not be generalizable to other economic and/or cultural contexts. Second, our sample is constrained in size, which is common in the context of research on SFOs (Welsh et al. 2013) and PE firms (Michel et al. 2020) given the small overall population, the difficulties in obtaining highly confidential financial data, and the lack of transparency (Amit et al. 2008; Cumming and Groh 2018). To mitigate these concerns, replication studies in similar and different cultural settings are encouraged. Third, we measured the ordinal dependent variable debt financing at a certain point of time (i.e., the time of the interview), which further limits the generalizability of our results. 
Although we followed the suggested debt categorization by Schulze et al. (2003), empirical longitudinal studies would be helpful to better capture generational, temporal, and market differences in capital structure decisions within SFOs and PE firms.

Funding Open Access funding enabled and organized by Projekt DEAL.

Open Access This article is licensed under a Creative Commons Attribution 4.0 International License, which permits use, sharing, adaptation, distribution and reproduction in any medium or format, as long as you give appropriate credit to the original author(s) and the source, provide a link to the Creative Commons licence, and indicate if changes were made. The images or other third party material in this article are included in the article's Creative Commons licence, unless indicated otherwise in a credit line to the material. If material is not included in the article's Creative Commons licence and your intended use is not permitted by statutory regulation or exceeds the permitted use, you will need to obtain permission directly from the copyright holder. To view a copy of this licence, visit http://creativecommons.org/licenses/by/4.0/.

\section{References}

Amit, R., Liechtenstein, H., Prats, M.J., Millay, T., \& Pendleton, L.P. (2008). Single family offices: Private wealth management in the family context. Research report. Philadelphia: Wharton University.

Amore, M. D., Minichilli, A., \& Corbetta, G. (2011). How do managerial successions shape corporate financial policies in family firms? Journal of Corporate Finance, 17(4), 10161027. https://doi.org/10.1016/j.jcorpfin.2011.05.002.

Ampenberger, M., Schmid, T., Achleitner, A. K., \& Kaserer, C. (2013). Capital structure decisions in family firms: Empirical evidence from a bank-based economy. Review of Managerial Science, 7(3), 247-275. https://doi.org/10.1007/s1 1846-0110077-2.

Anderson, R. C., \& Reeb, D. M. (2003). Founding-family ownership, corporate diversification, and firm leverage. Journal of Law and Economics, 46(2), 643-680. https://doi.org/10.1086 137711 .

Ariely, D., Huber, J., \& Wertenbroch, K. (2005). When do losses loom larger than gains? Journal of Marketing Research, 42(2), 134-138. https://doi.org/10.1509/jmkr.42.2.134.62283.

Axelson, U., Jenkinson, T., Stroemberg, P., \& Weisbach, M. S. (2013). Borrow cheap, buy high? The determinants of leverage and pricing buyouts. The Journal of Finance, 67(6), 2223-2267. https://doi.org/10.1111/jofi.12082.

Bacci, S., Cirillo, A., Mussolino, D., \& Terzani, S. (2018). The influence of family ownership dispersion on debt level in privately held firms. Small Business Economics, 51(3), 557579. https://doi.org/10.1007/s11187-017-9930-2.

Barry, C. B., \& Mihov, V. T. (2015). Debt financing, venture capital, and the performance of initial public offerings. Journal of Banking \& Finance, 58, 144-165. https://doi. org/10.1016/j.jbankfin.2015.04.001.
Barton, S. L., \& Matthews, C. H. (1989). Small firm financing: Implications from a strategic management perspective. Journal of Small Business Management, 27(1), 1-7. https://doi.org/10.1080/1331677X.2019.1677488.

Berrone, P., Cruz, C., Gómez-Mejía, L. R., \& Larraza-Kintana, M. (2010). Socioemotional wealth and corporate responses to institutional pressures: Do family-controlled firms pollute less? Administrative Science Quarterly, 55(1), 82-113. https://doi.org/10.2189/asqu.2010.55.1.82.

Bierl, P., \& Kammerlander, N. (2019). Family equity as transgenerational mechanism for entrepreneurial families. Journal of Family Business Management, in press. https://doi.org/10.1108/JFBM-09-2018-0043.

Blanco-Mazagatos, V., Quevedo-Puente, E., \& Castrillo, L. (2007). The trade-off between financial resources and agency costs in the family business: An exploratory study. Family Business Review, 20(3), 199-213. https://doi.org/10.1111 /j.1741-6248.2007.00095.x.

Block, J., Colombo, M., Cumming, D., \& Vismara, S. (2018). New players in entrepreneurial finance and why they are there. Small Business Economics, 50(2), 239-250. https://doi.org/10.1007/s11187-016-9826-6.

Block, J., Fisch, C., Vismara, S., \& Andres, R. (2019). Private equity investment criteria: An experimental conjoint analysis of venture capital, business angels, and family offices. Journal of Corporate Finance, 58, 329-352. https://doi. org/10.1016/j.jcorpfin.2019.05.009.

Bopaiah, C. (1998). Availability of credit to family businesses. Small Business Economics, 11(1), 75-86. https://doi. org/10.1023/A:1007944811224.

Bush, S. (2015). Sample size determination for logistic regression: A simulation study. Communications in Statistics: Simulation and Computation, 44(2), 360-373. https://doi. org/10.1080/03610918.2013.777458.

Chang, S. J., Van Witteloostuijn, A., \& Eden, L. (2010). From the editors: Common method variance in international business research. Journal of International Business Studies, 41(2), 178-184. https://doi.org/10.1057/jibs.2009.88.

Chirico, F., Gómez-Mejia, L. R., Hellerstedt, K., Withers, M., \& Nordqvist, M. (2019). To merge, sell, or liquidate? Socioemotional wealth, family control, and the choice of business exit. Journal of Management, in press. https://doi. org/10.1177/0149206318818723.

Chrisman, J. J., \& Patel, P. C. (2012). Variations in R\&D investments of family and non-family firms: Behavioral agency and myopic loss aversion perspectives. Academy of Management Journal, 55(4), 976-997. https://doi. org/10.5465/amj.2011.0211.

Chung, J. W., Sensoy, B. A., Stern, L., \& Weisbach, M. S. (2012). Pay for performance from future fund flows: The case of private equity. The Review of Financial Studies, 25(11), 3259-3304. https://doi.org/10.1093/rfs/hhr141.

Cohen J. (1988). Statistical power and analysis for the behavioral sciences. 2nd ed. Hisdale, NJ: Lawrence Erlbaum Associates; pp. $79-80$.

Crampton, S. M., \& Wagner, J. A. (1994). Percept-percept inflation in microorganizational research: An investigation of prevalence and effect. Journal of Applied Psychology, 79(1), 67-76. https://doi.org/10.1037/0021-9010.79.1.67.

Cruz, C., Justo, R., \& De Castro, J. O. (2010). Does family employment enhance MSEs performance? Integrating 
socioemotional wealth and family embeddedness perspectives. Journal of Business Venturing, 27(1), 62-76. https://doi.org/10.1016/j.jbusvent.2010.07.002.

Cumming, D., \& Groh, A. P. (2018). Entrepreneurial finance: Unifying themes and future directions. Journal of Corporate Finance, 50, 538-555. https://doi.org/10.1016/j. jcorpfin.2018.01.011.

Cyert, R.M., \& March, J.G. (1963). A behavioral theory of the firm. Englewood Cliffs, NJ, USA: Prentice-Hall 2nd edition. N10.2139/ssrn.3102588.

Dawson, A. (2011). Private equity investment decisions in family firms. The role of human resources and agency costs. Journal of Business Venturing, 26(2), 189-199. https://doi. org/10.1016/j.jbusvent.2009.05.004.

De Massis, A., Audretsch, D., Uhlaner, L., \& Kammerlander, N. (2018). Innovation with limited resources: Management lessons from the German Mittelstand. Journal of Product Innovation Management, 35(1), 125-146. https://doi. org/10.1111/jpim.12373.

Debicki, B. J., Kellermanns, F. W., Chrisman, J. J., Pearson, A. W., \& Spencer, B. A. (2016). Development of a socioemotional wealth importance (SEWi) scale for family firm research. Journal of Family Business Strategy, 7(1), 4757. https://doi.org/10.1016/j.jfbs.2016.01.002.

Decker, C., \& Lange, K. (2013). Exploring a secretive organization: What can we learn about family offices from the public sphere? Organizational Dynamics, 42(4), 298-306. https://doi.org/10.1016/j.orgdyn.2013.07.008.

Dickson, P. H., Weaver, K. M., \& Hoy, F. (2006). Opportunism in the R\&D alliances of SMEs, The roles of the institutional environment and SME size. Journal of Business Venturing, 21(4), 487-513. https://doi.org/10.1016/j. jbusvent.2005.02.003.

Dillman, D. A. (1978). Mail and telephone surveys: The total design method. Wiley, New York, USA. https://doi. org/10.1080/07377366.1982.10401298.

Douglas, E. J., \& Shepherd, D. A. (2000). Entrepreneurship as a utility maximizing response. Journal of Business Venturing, 15(3), 231-225. https://doi.org/10.1016/S0883-9026(98 )00008-1.

Gallo, M., \& Vilaseca, A. (1996). Finance in family business. Family Business Review, 9(4), 387-401. https://doi. org/10.1111/j.1741-6248.1996.00387.x.

Gallo, M., Tapies, J., \& Cappuyns, K. (2004). Comparison of family and nonfamily business: Financial logic and personal preferences. Family Business Review, 17(4), 303-318. https://doi.org/10.1111/j.1741-6248.2004.00020.x.

Gómez-Mejía, L. R., Haynes, K., Nuñez-Nickel, M., Jacobson, K., \& Moyano-Fuentes, F. (2007). Socioemotional wealth and business risks in family controlled firms. Administrative Science Quarterly, 52(1), 106-137. https://doi.org/10.2189 /asqu.52.1.106.

Gómez-Mejía, L. R., Makri, M., \& Larraza-Kintana, M. (2010). Diversification decisions in family-controlled firms. Journal of Management Studies, 47(2), 223-252. https://doi. org/10.1111/j.1467-6486.2009.00889.x.

Gómez-Mejía, L. R., Patel, P. C., \& Zellweger, T. (2018). In the horns of the dilemma: Socioemotional wealth, financial wealth, and acquisitions in family firms. Journal of Management, 44(4), 1369-1397. https://doi.org/10.1177 /0149206315614375.
Gompers, P., Kaplan, S. N., \& Mukharlyamov, V. (2016). What do private equity firms say they do? Journal of Financial Economics, 121(3), 449-476. https://doi.org/10.1016/j. jfineco.2016.06.003.

González, M., Guzmán, A., Pombo, C., \& Trujillo, M. A. (2013). Family firms and debt: Risk aversion versus risk of losing control. Journal of Business Research, 66(11), 2308-2320. https://doi.org/10.1016/j.jbusres.2012.03.014.

Gottardo, P., \& Moisello, A. M. (2014). The capital structure choices of family firms. Managerial Finance, 40(3), 254 275. https://doi.org/10.1108/MF-03-2013-0065.

Hair, J. F., Black, W., Babin, B., \& Anderson, R. (2010). Multivariate data analysis. A global perspective. Bergen: Pearson Prentice Hall.

Harris, M., \& Raviv, A. (1991). The theory of capital structure. Journal of Finance, 46(1), 297-355. https://doi.org/10.1111 j.1540-6261.1991.tb03753.x.

Hutchinson, R. W. (1995). The capital structure and investment decisions of the small owner-managed firm: Some exploratory issues. Small Business Economics, 7(3), 231-239. https://doi.org/10.1007/BF01135368.

Jensen, M. C., \& Meckling, W. H. (1976). Theory of the firm: Managerial behavior, agency costs and ownership structure. Journal of Financial Economics, 3(4), 305-360. https://doi. org/10.1016/0304-405X(76)90026-X.

Kahneman, D., \& Tversky, A. (1979). Prospect theory: An analysis of decision under risk. Econometrica, 47(2), 263-292. https://doi.org/10.2307/1914185.

Kempers, M., Leitterstorf, M., \& Kammerlander, N. (2017). Risk behavior of family firms: A literature review, framework, and research agenda. In E. Memili \& C. Dibrell (Eds.), The Palgrave handbook of heterogeneity among family firms. London: Palgrave Macmillan. https://doi.org/10.1007/9783-319-77676-7_16.

King, M. R., \& Santor, E. B. (2008). Family values: Ownership structure and performance of Canadian firms. Journal of Banking \& Finance, 32(11), 2423-2432. https://doi. org/10.2139/ssrn.967812.

Kline, P. (2013). Handbook of psychological testing. London: Routledge. https://doi.org/10.4324/9781315812274.

Koropp, C., Grichnik, D., \& Kellermanns, F. (2013). Financial attitudes in family firms: The moderating role of family commitment. Journal of Small Business Management, 51(1), 114-137. https://doi.org/10.1111/j.1540-627 X.2012.00380.x.

Kraus, A., \& Litzenberger, R. H. (1973). A state-preference model of optimal financial leverage. The Journal of Finance, 28(4), 911-922. https://doi.org/10.1111/j.1540-6261.1973. tb01415.x.

Lindell, M. K., \& Whitney, D. J. (2001). Accounting for common method variance in cross-sectional research designs. Journal of Applied Psychology, 86(1), 114-121. https://doi. org/10.1037/0021-9010.86.1.114.

Listenchampion (2017). Top 100 Family Offices DeutschlandListe der größten verwalteten Familien Vermögen. Retrieved from www.listenchampion.de.

Listenchampion (2018). Top 100 Private Equity Unternehmen Deutschland - Liste der größten Beteiligungsgesellschaften. Retrieved from www.listenchampion.de. 
Listenchampion (2020). Top 150 Private Equity Unternehmen Deutschland - Liste der größten Beteiligungsgesellschaften. Retrieved from www.listenchampion.de.

Long, J. S., \& Freese, J. (2014). Regression models for categorical dependent variables using stata (3rd ed.). College Station: Stata Press.

López-Gracia, J., \& Sánchez-Andújar, S. (2007). Financial structure of the family business: Evidence from a group of small Spanish firms. Family Business Review, 20(4), 269-287. https://doi.org/10.1111/j.1741-6248.2007.00094.x.

Lumpkin, G. T., \& Brigham, K. H. (2011). Long-term orientation and intertemporal choice in family firms. Entrepreneurship: Theory and Practice, 35(6), 1149-1169. https://doi. org/10.1111/j.1540-6520.2011.00495.x.

McConaughy, D. L., Matthews, C. H., \& Fialko, A. S. (2001). Founding family controlled firms: Performance, risk, and value. Journal of Small Business Management, 39(1), 3149. https://doi.org/10.1111/0447-2778.00004.

Michaelas, N., Chittenden, F., \& Poutziouris, P. (1999). Financial policy and capital structure choice in UK SMEs: Empirical evidence from company panel data. Small Business Economics, 12(2), 113-130. https://doi.org/10.1023 /A:1008010724051.

Michel, A., Ahlers, O., Hack, A., \& Kellermanns, F. W. (2020). Who is the king of the hill? On bargaining power in private equity buyouts. Long Range Planning, 53(2), 1-21. https://doi.org/10.1016/j.lrp.2018.11.003.

Michiels, A., \& Molly, V. (2017). Financing decisions in family businesses: A review and suggestions for developing the field. Family Business Review, 30(4), 369-399. https://doi. org/10.1177/0894486517736958.

Mietzner, M., \& Schweizer, D. (2014). Hedge funds versus private equity funds as shareholder activists in Germany: Differences in value creation. Journal of Economics and Finance, 38(2), 181-208. https://doi.org/10.1007/s12197-011-9203-x.

Mishra, C. S., \& McConaughy, D. L. (1999). Founding family control and capital structure: The risk of loss of control and the aversion to debt. Entrepreneurship: Theory and Practice, 23 ( 4), 53-64. https://doi.org/10.1177 $/ 104225879902300404$.

Molly, V., Laveren, E., \& Jorissen, A. (2012). Integrational differences in family firms: Impact on capital structure and growth behavior. Entrepreneurship: Theory and Practice, 36(4), 703-725. https://doi.org/10.1111/j.15406520.2010.00429.x.

Molly, V., Uhlaner, L. M., De Massis, A., \& Laveren, E. (2019). Family-centered goals, family board representation, and debt financing. Small Business Economics, 53(1), 269-286. https://doi.org/10.1007/s11187-018-0058-9.

Myers, S. C. (1977). Determinants of corporate borrowing. Journal of Financial Economics, 5(2), 145-175. https://doi. org/10.1016/0304-405X(77)90015-0.

Myers, S. C. (1984). The capital structure puzzle. Journal of Finance, 39(3), 575-592. https://doi.org/10.1111/j.15406261.1984.tb03646.x.

Myers, S. C., \& Majluf, N. S. (1984). Corporate financing and investment decisions when firms have information that investors do not have. Journal of Financial Economics, 13(2), 187-221. https://doi.org/10.1016/0304-405X(84)90023-0.

Pfaffermayr, M. (2009). Maximum likelihood estimation of a general unbalanced spatial random effects model: A Monte
Carlo study. Spatial Economic Analysis, 4(4), 476-483. https://doi.org/10.1080/17421770903317645.

Pierce, J. L., Kostova, T., \& Dirks, K. T. (2001). Toward a theory of psychological ownership in organizations. The Academy of Management Review, 26(2), 298-310. https://doi. org/10.5465/amr.2001.4378028.

Podsakoff, P. M., \& Organ, D. W. (1986). Self-reports in organizational research: Problems and perspectives. Journal of Management, 12(4), 531-544. https://doi.org/10.1177 /014920638601200408.

Podsakoff, P., MacKenzie, S., Lee, J., \& Podsakoff, N. (2003). Common method biases in behavioral research: A critical review of the literature and recommended remedies. Journal of Applied Psychology, 88(5), 879-903. https://doi. org/10.1037/0021-9010.88.5.879.

Poutziouris, P. (2001). The views of family companies on venture capital: Empirical evidence from the UK small to mediumsize enterprising economy. Family Business Review, 14(3), 277-291. https://doi.org/10.1111/j.1741-6248.2001.00277. $\mathrm{x}$.

Reid, R., Dunn, B., Cromie, S., \& Adams, J. (1999). Family orientation in family firms: A model and some empirical evidence. Journal of Small Business and Enterprise Development, 6(1), 55-66. https://doi.org/10.1108 /EUM0000000006668.

Rivo-López, E., Villanueva-Villar, M., Vaquero-Garcia, A., \& Lago-Penas, S. (2017). Family offices: What, why and what for. Organizational Dynamics, 46(4), 262-270. https://doi. org/10.1016/j.orgdyn.2017.03.002.

Romano, C. A., Tanewski, G. A., \& Smyrnios, K. X. (2001). Capital structure decision making: A model for family business. Journal of Business Venturing, 16(3), 285-310. https://doi.org/10.1016/S0883-9026(99)00053-1.

Rottke, O. N., \& Thiele, F. K. (2018). Do family investors differ from other investors? Similarity, experience, and professionalism in the light of family investee firm challenges. Journal of Business Economics, 88(2), 139-166. https://doi. org/10.1007/s11573-017-0871-7.

Schulze, W. S., Lubatkin, M., \& Dino, R. (2003). Exploring the agency consequences of ownership dispersion among the directors of private family firms. Academy of Management Journal, 46(2), 179-194. https://doi.org/10.5465/30040613.

Sharma, P., \& Manikutty, S. (2005). Strategic divestments in family firms: Role of family structure and community culture. Entrepreneurship: Theory and Practice, 29(3), 293311. https://doi.org/10.1111/j.1540-6520.2005.00084.x.

Schickinger, A., Bierl, P., Leitterstorf, M., \& Kammerlander, N. (2020). Family-related goals, entrepreneurial investment behavior, and governance mechanisms of single family offices: An exploratory study. Journal of Family Business Strategy, in press.

Sirmon, D. G., \& Hitt, M. A. (2003). Managing resources: Linking unique resources, management, and wealth creation in family firms. Entrepreneurship: Theory and Practice, 27(4), 339358. https://doi.org/10.1111/1540-8520.t01-1-00013.

Strebulaev, I. A., \& Yang, B. (2013). The mystery of zero-leverage firms. Journal of Financial Economics, 109(1), 1-23. https://doi.org/10.1016/j.jfineco.2013.02.001.

Stulz, R. (1990). Managerial discretion and optimal financing policies. Journal of Financial Economics, 26(1), 3-27. https://doi.org/10.1016/0304-405X(90)90011-N. 
Tan, J. J., \& Litschert, R. J. (1994). Environment-strategy relationship and its performance implications: An empirical study of the Chinese electronics industry. Strategic Management Journal, 15(1), 1-20. https://doi.org/10.2139 /ssrn.1552172.

Tourangeau, R., Rips, L. J., \& Rasinski, K. (2000). The psychology of survey responses. Cambridge: Cambridge University Press. https://doi.org/10.1017/CBO9780511819322.

Townsend, D. M., DeTienne, D., Yitshaki, R., \& Arthurs, J. D. (2009). The psychological ownership of entrepreneurial organizations: Theoretical and model development. Frontiers of Entrepreneurship Research, 29(6), 3.

Van Doorn, J., \& Verhoef, P. C. (2008). Critical incidents and the impact of satisfaction on customer share. Journal of Marketing, 72(4), 123-142. https://doi.org/10.1509 /jmkg.72.4.123.

Veith, A. (2008). Fund formation: Germany. In C. Cogut (Ed.), Private equity: Fund formation and transactions in 34 jurisdictions worldwide. Getting the Deal Through/ Law Business Research Limited: London, UK.

Welsh, D., Memili, E., Rosplock, K., Roure, J., \& Segurado, J. L. (2013). Perceptions of entrepreneurship across generations in family offices: A stewardship theory perspective. Journal of Family Business Strategy, 4(3), 213-226. https://doi. org/10.1016/j.jfbs.2013.07.003.

Wessel, S., Decker, C., Lange, K., \& Hack, A. (2014). One size does not fit all: Entrepreneurial families' reliance on family offices. European Management Journal, 32(1), 37-45. https://doi.org/10.1016/j.emj.2013.08.003.
Wiseman, R. M., \& Gómez-Mejía, L. R. (1998). A behavioral agency model of managerial risk taking. Academy of Management Review, 23(1), 133-153. https://doi. org/10.5465/amr.1998.192967.

Zellweger, T. M., \& Kammerlander, N. (2015). Family, wealth, and governance: An agency account. Entrepreneurship: Theory and Practice, 39(6), 1281-1303. https://doi. org/10.1111/etap.12182.

Zellweger, T. M., Eddleston, K. A., \& Kellermanns, F. W. (2010). Exploring the concept of familiness: Introducing family firm identity. Journal of Family Business Strategy, 1(1), 54-63. https://doi.org/10.1016/j.jfbs.2009.12.003.

Zellweger, T. M., Kellermanns, F. W., Chrisman, J. J., \& Chua, J. H. (2012a). Family control and family firm valuations by family CEOs: The importance of intentions for transgenerational control. Organization Science, 23, 851868. https://doi.org/10.1287/orsc.1110.0665.

Zellweger, T. M., Nason, R. S., \& Nordqvist, M. (2012b). From longevity of firms to transgenerational entrepreneurship of families: Introducing family entrepreneurial orientation. Family Business Review, 25(2), 136-155. https://doi. org/10.1177/0894486511423531.

Publisher's note Springer Nature remains neutral with regard to jurisdictional claims in published maps and institutional affiliations. 